\title{
GAMBARAN TINGKAT PENGETAHUAN IBU NIFAS TENTANG DIET SAAT MENYUSUI DI RS PKU MUHAMMADIYAH BANTUL YOGYAKARTA
}

\author{
Elvika Fit Ari Shanti dan Chindy Puspita Dewi \\ STIKES Jen.A.Yani Yogyakarta, Jalan Ringroad Barat Ambarketawang Gamping Sleman \\ Yogyakarta.Telp 0274-4342000 \\ Email: el_vicha@yahoo.co.id
}

\begin{abstract}
Background of Study: During lactation, women will have optimal weight gain, it causes mothers reduce their food so that interfere breast-milk production. Diet during breastfeeding may be done, but it must be done slowly. It is necessary to defend the body against infections, to prevent constipation and to begin the process of exclusive breastfeeding. Knowledge of this diet is very important for postpartum mothers who want to go on a diet to avoid malnutrition during childbirth and lactation. Preliminary results of study showed that it appeared in PKU Muhammadiyah Hospital in Bantul there are many postpartum mothers who do not know about the importance of diet during breastfeeding.
\end{abstract}

Objective of Study: This study aims to know about the level of knowledge of postpartum women about diet during breastfeeding in July 2014 at PKU Muhammadiyah Hospital in Bantul, Yogyakarta.

Research Methods: This study uses quantitative descriptive method, with survey approach. The population in this study is 58 postpartum women. To collect the data, this study uses accidental sampling technique. The samples taken amounted to 35 for women. The research data is primary data by using the research instrument in the form of a questionnaire and data analysis using univariate analysis

Results: The level of knowledge about understanding of diet postpartum women in both categories as many as 16 people (45.7\%), on the definition of a balanced diet as many as 31 people (88.6\%), on the correct diet while breast-feeding as many as 20 people $(57.1 \%)$, on dietary goals in less category as much as 23 people $(65.7 \%)$, on the principle of the diet as much as 22 people (62.9\%), on the terms of diet in both categories as many as 14 people $(40.0 \%)$, about the benefits diet in less category as much as 22 people $(62.9 \%)$.

Conclusion: The results of the level of knowledge of puerperal women while breastfeeding diet in PKU Muhammadiyah Hospital are in quite as many as 20 categories of puerperal women $(57.1 \%)$.

Keywords: Knowledge diet of breastfeeding, postpartum mothers 


\section{PENDAHULUAN}

Angka kematian ibu pada tahun 2013 mengalami kenaikan dibanding pada tahun 2012. Tahun 2013 sebesar $96,83 / 100.000$ kelahiran hidup sedangkan tahun 2012 sebesar 52,2/100.000 kelahiran. Jumlah kematian ibu yang terlaporkan dari sebesar 34 kasus kematian dengan perincian kematian pada ibu hamil sebanyak 3 kasus, kematian ibu bersalin 16 dan kematian ibu nifas sebanyak 15 kasus salah satunya adalah kasus malnutrisi ${ }^{1}$

Cakupan bayi yang mendapat ASI Eksklusif di provinsi DIY pada tahun sebesar 2007 sebesar 7.994 (34\%), meningkat $118(1,49 \%)$ dibanding tahun 2006. Angka ini belum mencapai target SPM (Standar Pelayanan Minimal) yaitu $40 \%$ sehingga perlu sosialisasi ASI pada ibu baru melahirkan untuk memberikan ASI nya secara Eksklusif sampai bayi selama 6 bulan (Dinkes DIY, 2008). Cakupan bayi yang diberi ASI eksklusif di Kabupaten Bantul tahun 2013 62,5\% menurun bila dibandingkan tahun 2012 sebanyak $63,51 \%^{2}$

Mengingat pentingnya ASI untuk tumbuh kembang bayi dan balita maka salah satu yang perlu mendapat perhatian adalah bagaimana agar ibu dapat tetap memberikan ASI kepada bayinya sampai umur 6 bulan, Kondisi yang sehat dan harus memenuhi nutrisi yang mengandung tiga zat gizi utama yang cukup jumlahnya baik zat tenaga, zat pembangun maupun zat pengatur. ${ }^{3}$

Selama masa laktasi, wanita mengalami peningkatan berat badan yang optimal maka setelah melahirkan akan memiliki berat badan yang lebih tinggi dari pada awal masa kehamilan. Sering kali ibu mengurangi konsumsi makanannya, akibatnya dapat menghambat produksi susu atau mengganggu status gizi ibu, selain itu rasa letih yang sering dirasakan ibu seiring dengan penurunan berat badan yang cepat akan berdampak buruk pada pengeluaran ASI, diet pada masa nifas perlu mendapat perhatian yang serius, karena diet yang diharapkan harus bermutu, bergizi tinggi, cukup kalori, tinggi protein, dan banyak mengandung cairan, tapi bukan diet yang mengurangi konsumsi zat-zat gizi. Menu makanan yang dikonsumsi adalah porsi cukup dan teratur, tidak terlalu asin, pedas dan berlemak, tidak mengandung alkohol, nikotin, serta bahan pengawet atau pewarna. ${ }^{5}$.

Diet selama menyusui boleh saja dilakukan, tetapi harus dilakukan dengan perlahan. Cara yang aman untuk menurunkan berat badan adalah dengan memadukan diet rendah lemak yang sehat dan olahraga dengan intensitas sedang. Penurunan berat badan secara cepat hanya akan membahayakan bayi dan akan berdampak buruk pada produksi ASI. Ibu menyusui juga sebaiknya tidak terburu-buru memutuskan untuk berhenti menyusui bayinya hanya untuk menurunkan berat badan. Ibu menyusui sebaiknya jangan mengurangi makan dan menurunkan berat badan minimal sampai bayi berusia enam minggu atau membatasi makanan di minggu awal laktasi karena hal ini hanya akan mengurangi produksi ASI. ${ }^{3}$

Rata-rata volume ASI ibu berstatus gizi baik sekitar 700-800 cc, sementara mereka yang berstatus gizi kurang hanya berkisar 500-600 cc. Jumlah ASI yang disekresikan pada enam bulan pertama sebesar 750 cc sehari. Sekresi padahari pertama hanya terkumpul sebanyak $50 \mathrm{cc}$ yang kemudian meningkat menjadi 500, 650, dan 750 cc, masing-masing pada hari kelima, bulan pertama, dan pada bulan ketiga. ${ }^{5}$

Setiap ibu menyusui bayinya selama 4 bulan saja, dia akan kehilangan $250 \times 30 \times 4$ kkal sama dengan 45000 kkal yang setara (9 kkal terkkandung dalam $1 \mathrm{~g}$ lemak) dengan 5 kilogram lemak. Ditambah dengan materi yang dikeluarkan ketika melahirkan, maka berat wanita menyusui sebanyak 10,35 kilogram. ${ }^{6}$ Keteraturan memberikan ASI akan membantu penurunan berat badan. Perhitungan tersebut didasarkan pada asumsi bahwa kegiatan fisik wanita tidak berubah, melakukan senam selama 15 menit atau bahkan lebih dalam sehari, penyusutan kalori akan lebih besar lagi. Berat badan sebagian wanita menyusui akan berkurang sekitar 0,5-1,0 kg/bulan. 
Kehilangan berat yang diperkenankan tidak melebihi 2 kilogram perbulan. Penurunan berat badan lebih dari $0,5-1 \mathrm{~kg}$ dan pembatasan kalori yang terlalu ketat akan mengganggu gizi dan kesehatan ibu serta dapat membuat ibu kurang dalam memproduksi ASI . 7

Berdasarkan data hasil studi pendahuluan yang dilakukan di Rumah Sakit PKU Muhammadiyah Bantul pada tanggal 12 Maret 2014 didapatkan data ibu nifas sejak bulan Januari sampai bulan februari tahun 2014 sebanyak 77 orang ibu nifas, Hasil dari wawancara kepada 10 $(12,10 \%)$ ibu nifas dan didapatkan hasil 7 $(9,09 \%)$ orang ibu nifas belum mengetahui bagaimana cara diet yang sehat agar ibu tidak mengalami kekurangan gizi dan juga mengurangi berat badannya, 1 (1,3\%) orang ibu nifas sudah mengetahui tentang bagaimana diet yang sehat, sedangkan 2 $(2,6 \%)$ orang ibu nifas mengatakan hanya pernah mendengar tentang pantang makan dan diet saat menyusui tetapi hanya sekedar tahu saja.

\section{METODOLOGI PENELITIAN}

Jenis penelitian ini adalah penelitian deskriptif kuantitatif, rancangan penelitian deskriptif dengan pendekatan survey. Pendekatan survey adalah suatu metode penelitian yang dilakukan tanpa melakukan intervensi terhadap subjek penelitian (masyarakat). ${ }^{8}$ Penelitian ini dilakukan di Rumah Sakit PKU Muhammadiyah Bantul Yogyakarta. Jumlah seluruh ibu nifas pada bulan Maret sampai Mei 2014 sebanyak 174 orang. Sampel dengan metode pengambilan accidental sampling. Besar sampel dalam penelitian ini berjumlah 35 orang ibu nifas normal.

\section{HASIL PENELITIAN}

1. Karakteristik responden

Penelitian ini berdasarkan usia, paritas, pendidikan, dan pekerjaan yang disajikan pada tabel berikut

Tabel 1. Distribusi Frekuensi Karakteristik Responden Berdasarkan Umur dan Pendidikan

\begin{tabular}{ccc}
\hline Karakteristik & $f$ & $\begin{array}{c}\text { Persentase } \\
(\%)\end{array}$ \\
\hline Umur & & \\
$<20$ tahun & 2 & 5,7 \\
$20-35$ tahun & 29 & 82,9 \\
$<35$ tahun & 4 & 11,4 \\
\hline Jumlah & 35 & 100,0 \\
\hline Pendidikan & & \\
SD & 0 & 0 \\
SMP & 7 & 20,0 \\
SMA & 23 & 65,7 \\
Perguruan & 5 & 14,3 \\
tinggi & & \\
\hline Jumlah & 35 & 100,0
\end{tabular}

Sumber: Data Primer 2014

Berdasarkan tabel 1 Dari tabel diatas diketahui distribusi frekuensi berdasarkan umur ibu nifas sebagian besar berumur 20-35 tahun yaitu sebanyak 29 responden $(82,9 \%)$. Distribusi frekuensi berdasarkan pendidikan, sebagian ibu nifasmemiliki pendidikan terakhir SMA yaitu sebanyak 23 responden $(65,7 \%)$.

\section{Analisis Univariat}

Distribusi frekuensi, tabulasi silang antara umur dan pendidikan dengan gambaran tingkat pengetahuan ibu nifas tentang diet saat menyusui di RS PKU Muhammadiyah Bantul Yogyakarta pada bulan Juli 2014, diuraikan sebagai berikut: 
a. Tabulasi silang umur dengan pengetahuan ibu nifas tentang diet saat

menyusui dapat dilihat pada tabel berikut

Tabel 2 Gambaran umur dengan pengetahuan ibu nifas

tentang diet saat menyusui

\begin{tabular}{|c|c|c|c|c|c|}
\hline Umur & Baik & Cukup & Kurang & \multicolumn{2}{|c|}{ Jumlah } \\
\hline & $\%$ & $\%$ & $\%$ & $f$ & $\%$ \\
\hline$<20$ & 2,9 & 2,9 & 0 & 2 & 5,7 \\
\hline $20-35$ & 1131,4 & 1645,7 & 5,7 & 29 & 82,9 \\
\hline$>35$ & 2,9 & 8,6 & 0 & 4 & 11,4 \\
\hline Jumlah & $13 \quad 37,1$ & $20 \quad 57,1$ & 5,7 & 35 & 100,0 \\
\hline
\end{tabular}

Sumber data Primer 2014

Tabel 2. Menunjukkan bahwa sebagian besar responden berumur 20-35 tahun dengan pengetahuan tentang diet saat menyusui dalam kategori cukup sebanyak 16 responden $(45,7 \%)$. b. Tabulasi silang pendidikan dengan pengetahuan ibu nifas tentang diet saat menyusui

Tabel 3. Gambaran pendidikan dengan pengetahuan ibu nifas tentang diet saat menyusui

\begin{tabular}{ccccccccr}
\hline Pendidikan & \multicolumn{2}{c}{ Baik } & \multicolumn{2}{c}{ Cukup } & \multicolumn{2}{c}{ Kurang } & \multicolumn{2}{c}{ Jumlah } \\
\hline & $f$ & $\%$ & $f$ & $\%$ & $f$ & $\%$ & $f$ & $\%$ \\
\hline SD & 0 & 0 & 0 & 0 & 0 & 0 & 0 & 0 \\
SMP & 0 & 0 & 6 & 17,1 & 1 & 2,9 & 7 & 20,0 \\
SMA & 10 & 28,6 & 12 & 34,3 & 1 & 2,9 & 23 & 65,7 \\
PT & 3 & 8,6 & 2 & 5,7 & 0 & 0 & 5 & 14,3 \\
\hline Jumlah & 13 & 37,1 & 20 & 57,1 & 2 & 5,7 & 35 & 100,0 \\
\hline
\end{tabular}

\section{Sumber : Data Primer, 2014}

Berdasarkan tabel 3 bahwa sebagian besar responden berpendidikan terakhir SMA dengan pengetahuan tentang diet saat menyusui dalam kategori cukup sebanyak 12 responden $(34,3 \%)$.

c. Gambaran tingkat pengetahuan ibu nifas tentang diet saat menyusui

Tabel 4 Distribusi Frekuensi Responden berdasarkan gambaran tingkat pengetahuan ibu nifas tentang diet saat menyusui :

\begin{tabular}{ccc}
\hline Pengetahuan & $f$ & Persentase $(\%)$ \\
\hline Baik & 13 & 34,3 \\
Cukup & 20 & 57,1 \\
Kurang & 2 & 5,7 \\
\hline Jumlah & 35 & 100
\end{tabular}

Sumber : Data primer, 2014

Tabel 4 menunjukkan bahwa sebagian besar ibu nifas memiliki tingkat pengetahuan dengan kategori cukup yaitu sebanyak 20 responden. d. Gambaran tingkat pengetahuan ibu nifas tentang diet saat menyusui 
Tabel 5 Distribusi frekuensi responden berdasarkan gambaran pengetahuan ibu nifas tentang diet saat menyusui

\begin{tabular}{lll} 
Pengetahuan & $F$ & Persentase(\%) \\
\hline
\end{tabular}

\begin{tabular}{|c|c|c|}
\hline \multicolumn{3}{|c|}{ Syarat diet saat menyusui } \\
\hline Baik & 14 & 40,0 \\
\hline Cukup & 13 & 37,1 \\
\hline Kurang & 8 & 22,9 \\
\hline Jumlah & 35 & 100,0 \\
\hline \multicolumn{3}{|c|}{ Pengertian diet } \\
\hline Baik & 16 & 45,7 \\
\hline Cukup & 11 & 31,4 \\
\hline Kurang & 8 & 5,7 \\
\hline Jumlah & 35 & 100,0 \\
\hline \multicolumn{3}{|c|}{ Pengertian diet seimbang } \\
\hline Baik & 31 & 88,6 \\
\hline Cukup & 0 & 00,0 \\
\hline Kurang & 4 & 11,4 \\
\hline Jumlah & 35 & 100,0 \\
\hline \multicolumn{3}{|c|}{ Diet yang baik smenyusui } \\
\hline Baik & 12 & 34,3 \\
\hline Cukup & 20 & 57,1 \\
\hline Kurang & 3 & 8,6 \\
\hline Jumlah & 35 & 100,0 \\
\hline \multicolumn{3}{|c|}{ Tujuan diet saat menyusui } \\
\hline Baik & 12 & 34,3 \\
\hline Cukup & 0 & 00,0 \\
\hline Kurang & 23 & 65,7 \\
\hline Jumlah & 35 & 100,0 \\
\hline \multicolumn{3}{|c|}{ Prinsip diet saat menyusui } \\
\hline Baik & 22 & 62.9 \\
\hline Cukup & 7 & 20,0 \\
\hline Kurang & 6 & 17,1 \\
\hline Jumlah & 35 & 100,0 \\
\hline
\end{tabular}

\begin{tabular}{ccc}
\hline Manfaat diet saat menyusui & & \\
Baik & 4 & 11,4 \\
Cukup & 9 & 25,7 \\
Kurang & 22 & 62,9 \\
\hline Jumlah & 35 & 100,0 \\
\hline
\end{tabular}

\section{Sumber : Data Primer 2014}

Tabel 4. Menunjukkan bahwa gambaran tingkat pengetahuan ibu nifas tentang pengertian diet dalam kategori baik sebanyak 16 orang $(45,7 \%)$, tentang pengertian diet seimbang dalam kategori baik sebanyak 31 orang $(88,6 \%)$, tentang diet yang benar saat menyusui dalam kategori cukup sebanyak 20 orang, tentang tujuan diet saat menyusui dalam kategori kurang sebanyak 23 orang $(65,7)$, tentang prinsip diet saat menyusui dalam kategori baik sebanyak 22 orang $(62,9)$, tentang syarat diet saat menyusui dalam kategori baik sebanyak 14 orang $(40,0 \%)$, tentang manfaat diet saat menyusui dalam 
kategori kurang sebanyak 22 orang $(62,9 \%)$.

\section{PEMBAHASAN}

\section{Tingkat Pengetahuan tentang diet saat menyusui}

Berdasarkan hasil analisa dapat diketahui bahwa sebagian besar ibu nifas berumur 20-35 tahun sebanyak 29 orang $(82,9 \%)$, berpendidikan terakhir SMA sebanyak 23 orang $(65,7 \%)$, hasil analisa ini juga diketahui pengetahuan ibu nifas tentang diet saat menyusui di RS PKU Muhammadiyah Bantul Yogyakarta dalam kategori baik sebanyak 13 orang (34,3\%), dalam kategori cukup sebanyak 20 orang $(57,1 \%)$, dan dalam kategori kurang sebanyak 2 orang (5,7\%). Dapat disimpulkan bahwa pengetahuan ibu nifas tentang diet saat menyusui di RS PKU Muhammadiyah Bantul Yogyakarta dalam kategori cukup yaitu 20 ibu nifas $(57,1 \%)$. Pengetahuan dalam kategori cukup ini didukung dari karakteristik pendidikan rata-rata SMA sebanyak 23 orang $(65,7 \%)$. Hal ini sesuai dengan teori yang Budiman dan Riyanto (2013), yang menyatakan bahwa tingkat pendidikan dan umur merupakan salah satu faktor yang mempengaruhi pengetahuan seseorang, secara umum seseorang yang berpendidikan lebih tinggi akan mempunyai pengetahuan yang luas dibandingkan dengan seseorang yang tingkat pendidikannya lebih rendah. Sedangkan menurut Notoatmodjo (2010), pengetahuan merupakan domain yang sangat penting untuk terbentuknya tindakan seseorang, berdasarkan pengalaman dan penelitian ternyata perilaku yang didasari pengetahuan akan lebih tahan lama dari pada perilaku yang tidak didasari pengetahuan

\section{Tingkat pengetahuan ibu nifas tentang pengertian diet}

Berdasarkan hasil analisis dapat diketahui bahwa tingkat pengetahuan ibu nifas tentang pengertian diet di RSPKU Muhammadiyah Bantul Yogyakarta dalam kategori baik sebanyak 16 responden $(45,7 \%)$, mayoritas ibu nifas bisa menjawab pernyataan tentang pengertian diet. Secara umum ibu sudah mampu mengerti pengertian diet. Tingkat pengetahuan ibu dalam kategori baik dapat dipengaruhi oleh perkembangan media informasi yang sudah maju sehingga memudahkan ibu untuk memperoleh informasi tentang kesehatan, adapun faktor lain yang mempengaruhi tingkat pengetahuan ibu adalah pendidikan terakhir ibu yang mayoritas SMA yaitu sebanyak 23 ibu nifas $(65,7 \%)$ dan umur ibu berada pada rentang 20-35 tahun sebanyak 29 ibu nifas $(82,9 \%)$, sehingga lebih mudah untuk menerima informasi. Pengetahuan tentang pengertian diet ini termasuk dalam kategori "tahu" menurut Budiman dan Riyanto (2013). Tahu berarti dapat mengingat suatu materi yang dipelajari sebelumnya (recall).

\section{Tingkat pengetahuan ibu nifas tentang pengertian diet seimbang}

Berdasarkan hasil penelitian tingkat pengetahuan ibu nifas tentang pengertian diet seimbang di RS PKU Muhammadiyah Bantul Yogyakarta dalam kategori baik yaitu sebanyak 31 orang ibu nifas $(88,6 \%)$, sebagian besar ibu dapat menjawab pertanyaan tentang bagaimana diet yang seimbang dengan baik sehingga sebagian besar ibu menjawab pernyataan tentang bagaimana diet yang seimbang dengan benar dan hanya beberapa ibu nifas saja yang menjawab salah sehingga didapatkan hasil tingkat pengetahuan dengan kategori baik. Faktor lain adalah Usia pada rentang 20-35 tahun sebanyak $(82,9 \%)$ karena ibu-ibu pada rentang usia tersebut masih dianggap muda sehingga banyak ibu yang tertarik untuk melakukan diet.

\section{Tingkat pengetahuan ibu nifas tentang diet yang benar saat menyusui}

Berdasarkan hasil analisis dapat diketahui bahwa tingkat pengetahuan ibu nifas tentang diet yang benar saat menyusui di RS PKU Muhammadiyah 
Bantul Yogyakarta dalam kategori cukup sebanyak 20 orang ibu nifas (57,1\%). Sebagian besar responden kurang paham tentang diet yang benar saat menyusui dan kebutuhan nutrisi yang harus dipenuhi saat sedang masa menyusui khususnya tentang bagaimana pengaruh diet terhadap ASI bila dan juga terhadap tubuh ibu sendiri bila diet yang dilakukan berlebihan tidak dilakukan dengan cara yang seharusnya, hal ini mungkin bisa disebabkan karena ibu menganggap bahwa diet adalah mengurangi makan dan minum secara berlebihan agar dietnya cepat berhasil. ${ }^{14}$ Ada juga faktor lain yang mempengaruhi adalah karena kurangnya akses informasi yang dimiliki ibu sehingga informasi dan pengetahuan yang dimiliki ibu juga kurang, dan mungkin juga ibu tidak tertarik untuk melakukan diet karena ibu menganggap bahwa tubuhnya tidak memerlukan diet. Selain dari faktor tersebut juga ada faktor tingkat pendidikan dan usia ibu yang rata-rata berpendidikan SMA $(65,7 \%)$ dan usia berada pada rentang usia 20-35 tahun $(82,9 \%)$. Pengetahuan tentang pengertian diet seimbang ini termasuk dalam kategori "tahu", menurut Notoatmodjo (2010), tahu hanya diartikan sebagai recall (memanggil) memori yang telah ada sebelumnya setelah mengamati sesuatu.

\section{Tingkat pengetahuan ibu nifas tentang tujuan diet saat menyusui}

Berdasarkan hasil analisis dapat diketahui bahwa tingkat pengetahuan ibu nifas tentang tujuan diet dalam kategori kurang sebanyak 23 reponden $(65,7 \%)$, responden dengan tingkat pengetahuan kategori kurang tidak paham tentang tujuan diet saat menyusui, sebagian besar ibu menjawab salah pada pernyataan tentang tujuan diet saat menyusui, hal tersebut juga disebabkan oleh kurangnya tingkat pemahaman ibu pada pernyataan yang memuat tentang tujuan diet saat menyusui, ibu kurang mendapatkan informasi, serta ibu tidak tahu tentang tujuan diet, bahwa selain dapat membantu ibu untuk mengurangi berat badannya seperti sebelum hamil dan melahirkan diet juga dapat membantu ibu dalam memperbaiki kondisi tubuh ibu setelah melahirkan ataupun memperbaiki kurang gizi yang dialami bila diet yang dilakukan ibu tetap memperhatikan jumlah kandungan nutrisi yang harus dipenuhi.

Pengetahuan terhadap kuantitas dan kualitas makanan pada saat ibu menyusui sangat mempengaruhi produksi ASI, jika keadaan gizi ibu baik secara kuantitas, akan ASI pun akan diproduksi dengan lebih banyak daripada ibu dengan gizi yang kurang.$^{15}$

\section{Tingkat pengetahuan ibu nifas tentang prinsip diet saat menyusui}

Berdasarkan hasil penelitian dapat diketahui bahwa tingkat pengetahuan ibu nifas tentang prinsip diet saat menyusui dalam kategori baik sebanyak 22 responden $(62,9 \%)$, sebagian besar ibu nifas bisa menjawab pertanyaan yang diberikan dengan benar tentang prinsip diet yang benar saat menyusui. Pengetahuan yang baik menunjukan bahwa ibu mengerti tentang prinsip diet yang seharusnya yaitu tinggi kalori dan tinggi protein, cukup cairan, cukup lemak dan juga cukup mineral dan juga cukup olahraga. Selain dari tingkat pemahaman dan banyaknya informasi yang diterima ada juga faktor pendidikan dan usia yang mempengaruhi tingkat pengetahuan ibu karena kedua faktor tersebut juga merupakan penunjang untuk menentukan tingkat pengetahuan yang dimiliki oleh seseorang, pada umumnya semakin tinggi tingkat pendidikan dan usia seseorang maka semakin mudah bagi seseorang tersebut menerima informasi yang diberikan. Pengetahuan tentang prinsip diet ini dikelompokkan dalam kategori "tahu". Menurut Notoatmodjo (2010) bahwa "tahu diartikan sebagai recall (memanggil) memori sebelumnya setelah mengamati sesuatu.

\section{Tingkat pengetahuan ibu nifas tentang syarat diet saat menyusui}

Berdasarkan hasil analisa dapat diketahui bahwa tingkat pengetahuan ibu nifas tentang syarat diet saat menyusui di RS PKU Muhammadiyah Bantul 
Yogyakarta dalam kategori baik sebanyak 14 ibu nifas (40,0\%). Sebagian besar ibu nifas menjawab pertanyaan yang diberikan tentang syarat diet yang benar saat menyusui.Menurut Adriani dan Wirjatmadi (2012) syarat diet saat menyusui susunan hidangan sehari-hari harus seimbang yang terdiri dari makanan pokok, lauk-pauk, sayuran, dan buahbuahan, Hindari makanan yang merangsang seperti terlalu pedas (bumbu), terlalu dingin, terlalu panas, mengandung alkohol, untuk menjaga kelancaran alat-alat pencernaa minum dalam jumlah lebih besar kurang lebih 6 gelas dalam sehari, akan lebih bermanfaat bila ibu menyusui minum-minumanbergizi seperti susu, air kacang-kacangan, sari buah-buahan, air sayuran daun hijau, dan sebagainya.

Pengetahuan yang baik ini menunjukkan bahwa ibu bisa menjawab pernyataan tentang syarat diet dengan benar dan juga ibu memahami pengaturan makan yang seharusnya saat menyusui meskipun ibu sedang melakukan diet serta makanan dan minuman apa saja yang diperbolehkan untuk dikonsumsi oleh ibu supaya dietnya dapat berjalan dengan baik dan juga tidak berpengaruh buruk terhadap ASI. Faktor lain yang menyebabkan tingkat pengetahuan ibu juga berasal dari tingkat pendidikan dan juga usia ibu yang masih bisa disebut dengan ibu muda yang masih memerlukan ukuran tubuh yang ideal.

\section{Tingkat pengetahuan ibu nifas tentang manfaat diet saat menyusui}

Berdasarkan hasil penelitian dapat diketahui bahwa tingkat pengetahuan ibu nifas tentang manfaat diet saat menyusui dalam kategori kurang sebanyak 22 orang ibu nifas (62,9\%). Sebagian besar ibu tidak tahu tentang manfaat diet saat menyusui, hal tersebut disebabkan karena kurangnya informasi yang dimiliki oleh ibu. Pada umumnya semakin tinggi tingkat pendidikan dan juga usia seseorang maka semakin mudah juga bagi orang tersebut untuk menerima informasi yang diberikan

\section{KESIMPULAN}

1. Gambaran tingkat pengetahuan ibu nifas tentang diet saat menyusui dalam kategori cukup yaitu sebanyak 20 ibu nifas (57,1\%).

2. Gambaran tingkat pengetahuan ibu nifas di RS PKU Muhammadiyah Bantul Yogyakarta tentang pengertian diet dalam kategori baik yaitu sebanyak 16 ibu nifas (45,7\%).

3. Gambaran tingkat pengetahuan ibu nifas di RS PKU Muhamadiyah Bantul Yogyakarta tentang pengertian diet seimbang dalam kategori baik sebanyak 31 ibu nifas (88,6\%).

4. Gambaran tingkat pengetahuan ibu nifas tentang cara diet yang benar saat menyusui dalam kategori cukup yaitu sebanyak 20 ibu nifas $(57,1 \%)$.

5. Gambaran tingkat pengetahuan ibu nifas tentang tujuan diet saat menyusui dalam kategori kurang yaitu sebanyak 23 ibu nifas $(65,7 \%)$

6. Gambaran tingkat pengetahuan ibu nifas tentang prinsip diet saat menyusui di RS PKU Muhammadiyah Bantul Yogyakarta dalam kategori baik yaitu sebanyak 22 ibu nifas (62,9\%).

7. Gambaran tingkat pengetahuan ibu nifas tentang syarat diet saat menyusui di RS PKU Muhammadiyah Bantul Yogyakarta dalam kategori baik yaitu sebanyak 14 ibu nifas (40,0\%).

8. Gambaran tingkat pengetahuan ibu nifas tentang manfaat diet saat menyusui di RS PKU Muhammadiyah Bantul Yogyakarta dalam kategori kurang yaitu sebanyak 22 ibu nifas $(62,9 \%)$.

\section{SARAN}

Penelitian ini diharapkan dapat dijadikan sebagai referensi untuk bahan pembelajaran para petugas kesehatan yang ada di RS PKU Muhammadiyah Bantul supaya petugas kesehatan dapat memberikan penyuluhan dan sosialisasi kepada ibu nifas tentang cara diet yang benar saat menyusui, khususnya mengenai tujuan dan manfaat diet saat menyusui supaya para ibu nifas mengerti dan memahami pentingnya diet saat 
menyusui. Hal ini dapat dilakukan dengan cara melakukan penyuluhan, konseling, melalui media cetak, leaflet diberikan. Bagi Peneliti selanjutnya. metode penelitian yang lebih komplek dan dapat menggali berbagai faktor-faktor lain, sehingga dapat menjadi acuan diet pada ibu menyusui

\section{DAFTAR PUSTAKA}

1. Dinas Kesehatan DIY. (2013). Profil Kesehatan D.I.Y Tahun 2013.Yogyakarta : Dinkes D.I.Y.

2. Dinas kesehatan Bantul. (2014). Dinas Kesehatan Kabupaten Bantul Tahun 2014. Yogyakarta : Dinkes Bantul

3. Astuti, M, P. (2010). Ilmu Gizi Dalam keperawatan .Jakarta : Trans Info media

4. E. beck, M. (2011). IImu Gizi dan Diet Hubungannya dengan Pasien Untuk Dokter dan Perawat. Jakarta : Andi Offset

5. Kristiyansari, W. (2009). Asi, Menyusui, dan Sadari. Yogyakarta : Nuha medika

6. Almatsier, S. (2011).Gizi Seimbang Dalam Daur Kehidupan. Jakarta : Gramedia Pustaka Utama.
7. Saleha, S. (2009). Asuhan Kebidanan pada Masa nifas. Jakarta : Salemba Medika

8. Sugiyono. (2012). Metode penelitian Kuantitatif Kualitatif dan R\&D. Bandung : Alfabeta

9. Budiman, dan Riyanto, A. (2013).Kapita Selekta : Pengetahuan dan Sikap dalam Penelitian Kesehatan. Jakarta : Salemba Medika.

10. Notoatmodjo,S.(2010).Promosi Kesehatan dan IImu perilaku. Jakarta : Rineka

11. Ariani,A,P. (2014). Aplikasi Metodologi Penelitian Kebidanan dan Kesehatan Reproduksi. Yogyakarta : Nuha Medika.

12. Marmi. (2012). Asuhan Kebidanan Pada Masa Nifas "Puerperium Care". Yogyakarta : Pustaka pelajar

13. Maritalia, D. (2012). Asuhan Kebidanan Nifas dan Menyusui. Yogyakarta : Pustaka Pelajar.

14. Inayati, DA. 2006. Seputar status gizi ibu menyusui dan pemberian ASI

15. Adriani, M. dan Bambang, W. (2012). Peranan Gizi dalam Siklus Kehidupan. Jakarta : Kencana Prenada Media Group. 